\title{
Pericarp ontogenesis in wild species of Arachis L. (Leguminosae; Papilionoideae)
}

\author{
Carla Maria Garlet de Pelegrin ${ }^{a}$, José Francisco Montenegro Valls ${ }^{\mathrm{b}}$, Jorge Ernesto de Araujo Mariath ${ }^{\mathrm{a}, *}$

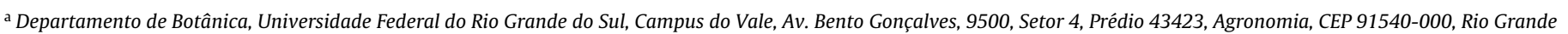 \\ do Sul, RS, Brazil \\ b Embrapa, Recursos Genéticos e Biotecnologia, Parque Estação Biológica, PqEB - Av. W5 Norte, CEP 70770-917, Brasília, DF, Brazil
}

\section{A R T I C L E I N F O}

\section{Article history:}

Received 22 May 2012

Accepted 9 January 2013

Available online 6 March 2013

\section{Keywords:}

Arachis

Fruit development

Fabaceae

Anatomy

Peanut

\begin{abstract}
A B S T R A C T
The genus Arachis encompasses 80 validly described species and the most striking characteristics is the geocarpic fruit, which occurs in every species of the genus. Taking into consideration that much of the current knowledge about this subject is based on the anatomy and morphology of A. hypogaea, a cultivated species with fruits that were modified during domestication, the objective of this study was to learn more about the development of the geocarpic fruits of wild species of Arachis (A. paraguariensis, A. pintoi, A. stenosperma, and A. tuberosa), and to provide characters that can be used in future phylogenetic works about this group. Buds, flowers and fruits at different stages of development were collected and processed according to standard methods used for light field, interferential contrast, and scanning electron microscopy. Although the geocarpic fruits of the wild species share many adaptations, this study identified potentially diagnostic infrageneric characters, such as the type of trichomes on the pericarp, the presence of sclerenchyma caps in the bundles of the pericarp of the seed chamber of the fruit and isthmus, the presence of tracheoid cells in the pith of the isthmus, the location of crystalliferous cells, the presence of tannins in the cells of mesocarp outer layers, and the presence of projections in the sclerenchyma tissue. In addition, this article brings some inferences about functional characteristics of this peculiar geocarpic fruit.
\end{abstract}

(C) 2013 Elsevier GmbH. All rights reserved.

\section{Introduction}

Arachis L. comprises 80 species (Krapovickas and Gregory, 1994; Valls and Simpson, 2005) and includes A. hypogaea L., the commercial peanut. According to Krapovickas and Gregory (1994), the main characteristics that define the genus are the subterranean structures, including the fruits, rhizomes, the root system and the hypocotyls. Arachis is presently divided into nine taxonomic sections (Arachis, Caulorrhizae, Erectoides, Extranervosae, Heteranthae, Procumbentes, Rhizomatosae, Trierectoides and Triseminatae) that are based on morphology, geographic distribution and the ability to form hybrids (Krapovickas and Gregory, 1994).

Geocarpy exists in all species of the genus and is characterized by the production of aerial flowers and by fruits and seeds that develop underground (Smith, 1950). Soon after fertilization, initial differentiation of the intercalary meristem occurs in the basal region of the ovary, which is the origin of a specialized structure that is usually called a peg or gynophore, and is involved in placing the fruit into the soil (Jacobs, 1947; Smith, 1950). Smith (1950) considered this structure as an elongation of the ovary, not a structure of

\footnotetext{
* Corresponding author.

E-mail address: jorge.mariath@ufrgs.br (J.E. de Araujo Mariath).
}

the receptacle that holds the gynoecium, and called it a gynophore. Even though this is controversial, the term gynophore is widely accepted in the literature and is used in the present work.

Based on morphology and anatomy, geocarpic fruits are peculiar, and the majority of studies on this fruit type have been about $A$. hypogaea (Halliburton et al., 1975; Haro et al., 2011; Periasamy and Sampoornam, 1984; Pettit, 1895; Reed, 1924; Russell, 1931; Smith, 1950; Tisserant, 1950; Waldron, 1919; Winton, 1904). In Arachis, besides $A$. hypogaea, only the structure of the wild species $A$. monticola Krapov. and Rigoni and $A$. villosa Benth., are known (Conagin, 1959). All these species are in section Arachis.

Anatomical characteristics of fruits are frequently overlooked in systematic works, because they are difficult to study (Bobrov et al., 2005). However, morphological and anatomical characters have been successfully used in taxonomy and ecology studies, because they exhibit little phenotypic plasticity and are involved in seed dispersal via biotic and abiotic agents (Barroso et al., 1999). In Leguminosae, the taxonomic significance of anatomical characters of the pericarp has been shown in various works (Lavin et al., 2001; Le Roux et al., 2011; Leite et al., 2009; Narang and Govil, 1978; Nemoto and Ohashi, 2003; Pate and Kuo, 1981). Yet, most of these studies only used mature fruits, which can lead to misinterpretations of both the structures of the fruits and their classification (Leite et al., 2009). 

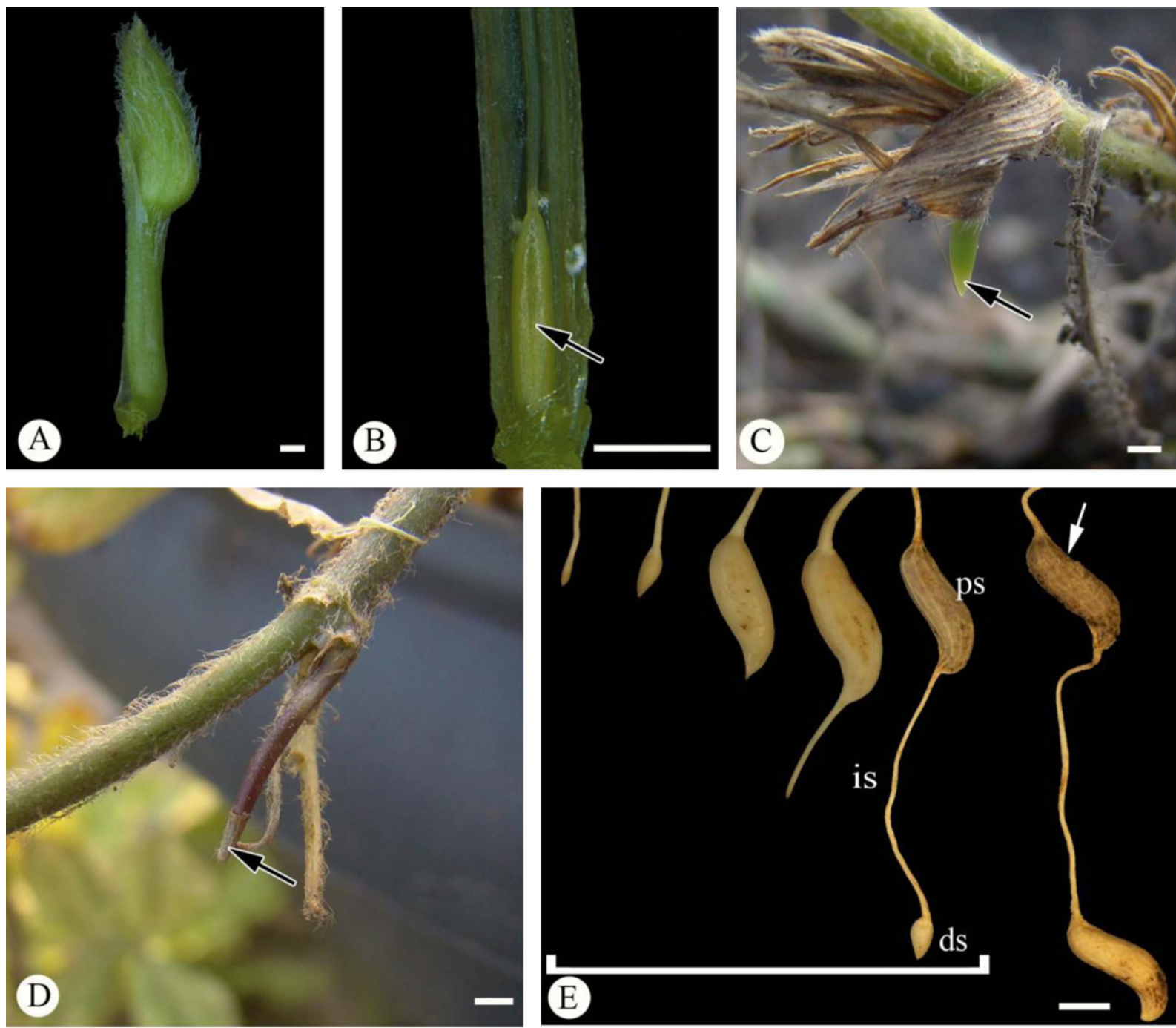

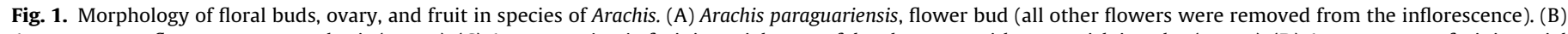

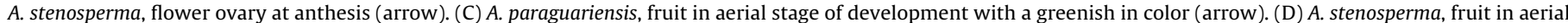

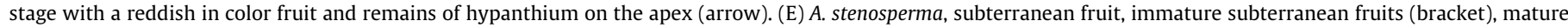
subterranean fruit with two segments (arrow). ds, distal segment; is, isthmus; ps, proximal segment. Bars in $(A)$ and $(B)=1 \mathrm{~mm},(C)$ and $(D)=2 \mathrm{~mm}$, $(E)=10 \mathrm{~mm}$.

Moreover, fruit studies can serve as a source of characters for phylogenetic studies, especially as it becomes increasingly necessary to add all available data, such as morphological, ontogenetic, biochemical and molecular, in an attempt to better understand relationships between plants (Doyle, 2000; Sytsma and Pirez, 2001).

Considering that anatomical studies on the fruits of wild species of Arachis are scarce, as well as the traditional use of carpological characters in Leguminosae systematics, the present study analyzed the ontogeny of the fruits of four wild species of this genus, which belong to different sections: Arachis stenosperma Krapov. and W.C. Greg. (Arachis), A. pintoi Krapov. and W.C. Greg. (Caulorrhizae), A. tuberosa Bong. ex Benth. (Trierectoides) and A. paraguariensis Chodat and Hassl.(Erectoides). The objective of this study was to analyze the development of the fruits of Arachis species and to provide characters that can be used in future phylogenetic works about this genus.

\section{Materials and methods}

Seeds of three of the species studied (A. stenosperma, A. pintoi and A. paraguariensis) were obtained from the Wild Arachis Genebank of Embrapa Recursos Genéticos e Biotecnologia (in Brasília, DF, Brazil) and cultivated in a greenhouse at the Universidade Federal do Rio Grande do Sul, Porto Alegre, RS, Brazil. Material of A. tuberosa was collected in the field, from a natural population, in the outskirts of Campo Grande, MS, Brazil. Voucher specimens were deposited in the Cenargen herbarium (CEN) (A. paraguariensis - JFM Valls, VR Rao, MAN Gerin and GP Silva 7677, A. pintoi - JFM Valls, DM Ramos and CMG Pelegrin 15385, A. stenosperma - JFM Valls, PG Bustamante, CM Castro and GP Silva 14453, and A. tuberosa - JFM Valls, A Pott, LC Costa and CMG Pelegrin 15441, 15442, and JFM Valls, A Pott, VJ Pott, LC Costa, FJM Caporal and CMG Pelegrin 15450).

Buds, flowers at anthesis, and fruits at different stages of development were collected from three or more individuals of each species (Fig. 1). The following developmental stages were defined to describe the species. I - Ovary of flower buds and of flowers at anthesis (Fig. 1A and B), II - Immature aerial fruit (Fig. 1C and D), III - Immature subterranean fruit (Fig. 1E- bracket), IV - Mature subterranean fruit (Fig. 1E- arrow).

The material was fixed in $1 \%$ glutaraldehyde and $4 \%$ formaldehyde in a $0.1 \mathrm{M}$ sodium phosphate buffer at $7.2 \mathrm{pH}$ (McDowell and Trump, 1976). To prepare the sections (transverse, longitudinal and paradermal) for histological analyses, samples were immersed in a $0.1 \mathrm{M}$ sodium phosphate buffer at $7.2 \mathrm{pH}$ (Gabriel, 
1982), dehydrated in an ethanolic series and included in (2hydroxyethyl)-methacrylate (Gerrits and Smid, 1983). The material was cut into $3-5 \mu \mathrm{m}$ sections using a Zeiss rotary microtome (Microm HM 340) with a glass knife and with a Leitz 1400 microtome using a steel knife. The sections were then stained with $0.05 \%$ toluidine blue, at $4.4 \mathrm{pH}$ (O'Brien and McCully, 1981). Histochemical tests were made with embedded and freehand sections of material, which were exposed to ruthenium red to test for pectins (Jensen, 1962), 10\% hydrochloric acid for calcium oxalate (Chamberlain, 1932), Sudan IV for lipids, periodic acid/Schiff's reagent (PAS) for polysaccharides (O'Brien and McCully, 1981), 1\% vanillin/ $\mathrm{HCl}$ for tannin (Guerin et al., 1971), and phloroglucinol/HCl for lignin (Sass, 1951). The analysis and the photomicrographs were made using a Leica DMR HC microscope coupled with a Leica DFC500 digital camera. To analyze the sclereids, pericarp samples were macerated in Jeffrey's solution (Johansen, 1940) for $48 \mathrm{~h}$, mounted on slides with glycerin gelatin and observed using Differential Interference Contrast microscopy (DIC) with the same microscope.

For the Scanning Electron Microscopy (SEM) analysis, the material was dehydrated in an ascending acetone series and critical point dried (Gerstberger and Leins, 1978). The samples were then mounted on aluminum stubs and coated with gold. Observations and electron micrographs were made using a JEOL 6060 microscope, at $10 \mathrm{kV}$. (1977).

The terminology used to define the pericarp layers follows Roth

\section{Results}

In order to facilitate the comparative analysis of wild species of Arachis we established four stages of fruit development:

Stage I: The initial stage of fruit development consists of the ovary in the flower buds before anthesis (Fig. 1A and B). As belonging to the Fabaceae family, the species of Arachis have flowers with a superior ovary, one carpel, one locule, with two ovules of parietal placentation (Fig. 2A), and it is possible to visualize the ventral suture line (Figs. 1B and 2B).

The outer epidermis of the ovary is uniseriate and, in transverse section, shows quadrangular to rectangular cells (Fig. 2B). The mesophyll is composed of parenchyma cells that are slightly globe-shaped. The first layer of mesophyll, which corresponds to the subepidermal layer, has discontinuous periclinal and anticlinal divisions, in both regions facing the outside of the ovary and the inside. The mesophyll cells in contact with the inner face of the epidermis exhibit visually smaller vacuoles, whereas cells in contact with the outer face of the epidermis are more vacuolated (Fig. 2B). Within the middle region of the mesophyll there are seven to ten provascular bundles and a dorsal collateral bundle with differentiated tracheary elements (Fig. 2B).

The epidermis of the inner surface is uniseriate, but can be biseriate, and is composed of cells with dense cytoplasm that are slightly periclinally elongate (Fig. 2B).

Stage II: This stage is represented by the temporarily aerial phase of fruit development. Only A. tuberosa has fruits that are near or on the ground where they are about to move into the soil and develop underground.

In this phase, the portion of the fruit exhibits intense meristematic activity (Fig. 3A). At this time a stalk-like structure develops and grows towards the soil, with the growing fruit at its apex (Fig. 1C and D). This structure, also called a gynophore, not only pushes the young fruit towards the soil but also the other floral parts (hypanthium, sepals, petals and stamens). These structures remain on top of the fruit for some time, at the apex of the gynophore (Fig. 1D), but fall off before the developing fruit is pushed underground.
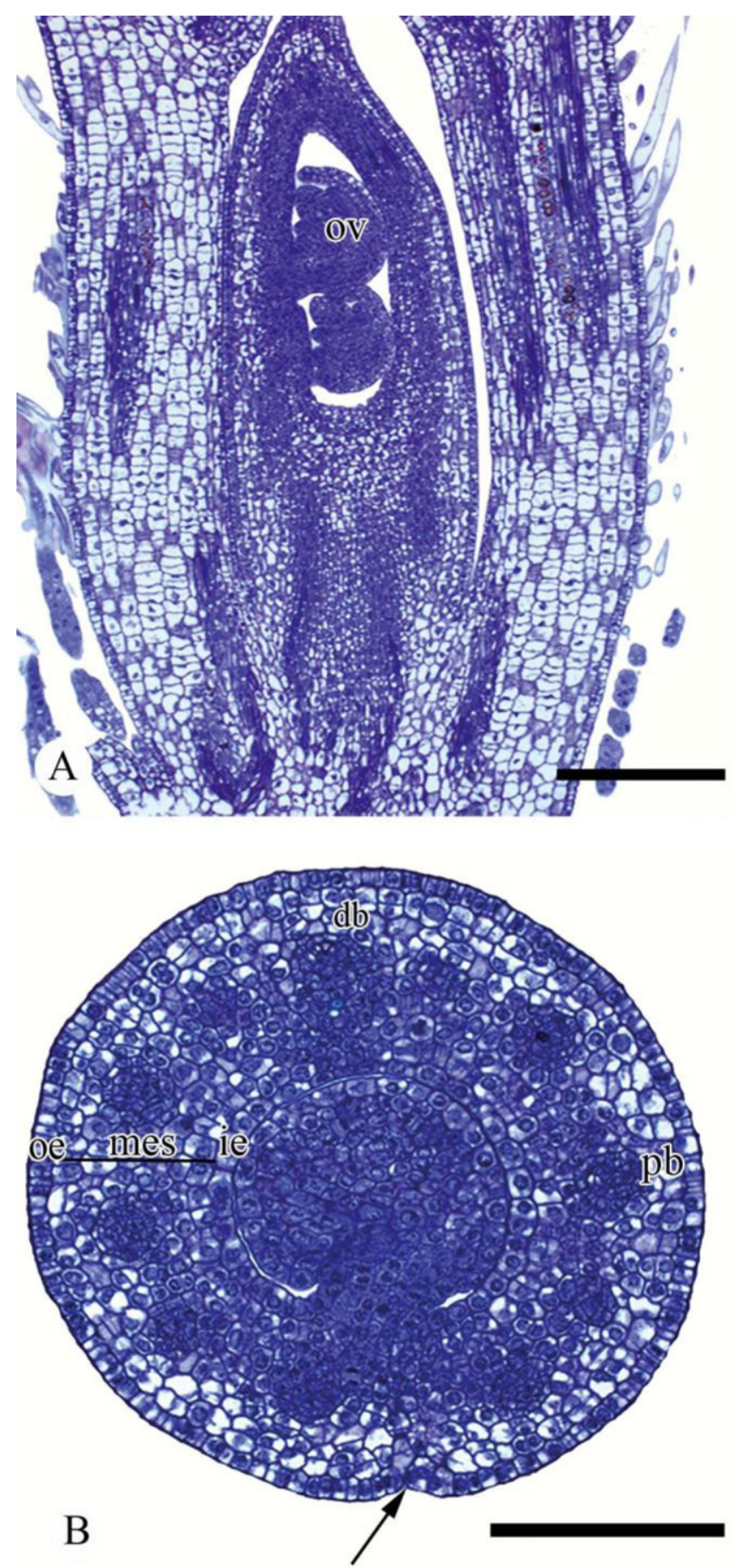

Fig. 2. Flower bud ovary of Arachis stenosperma. (A) Longitudinal section, ovary with one locule, parietal placentation. (B) Transversal section, ventral suture (arrow). db dorsal bundle; i.e., inner face of the epidermis; mes, mesophyll; oe, outer face of the epidermis; ov, ovule; pb, provascular bundle. Bars in $(A)=200 \mu \mathrm{m}$ and $(B)=100 \mu \mathrm{m}$.

During growth, while the fruit is descending towards the soil, the fruits of $A$. stenosperma (Fig. 1D) and A. pintoi are reddish in color, while those of $A$. paraguariensis (Fig. 1C) are greenish. In $A$. tuberosa, both the gynophore and the young fruit lack pigmentation most possibly because these structures are partially covered with soil.

The exocarp of Arachis is predominantly uniseriate (Fig. 3A, B, E and $\mathrm{F}$ ), with exception to the apical regions that can contain more than one cell layer, and consists of cells that are anticlinally elongated (Fig. 3A and B). In the apical regions of the fruit, the cells have outer periclinal walls that are pectin-rich (Fig. 3B). In the distal 

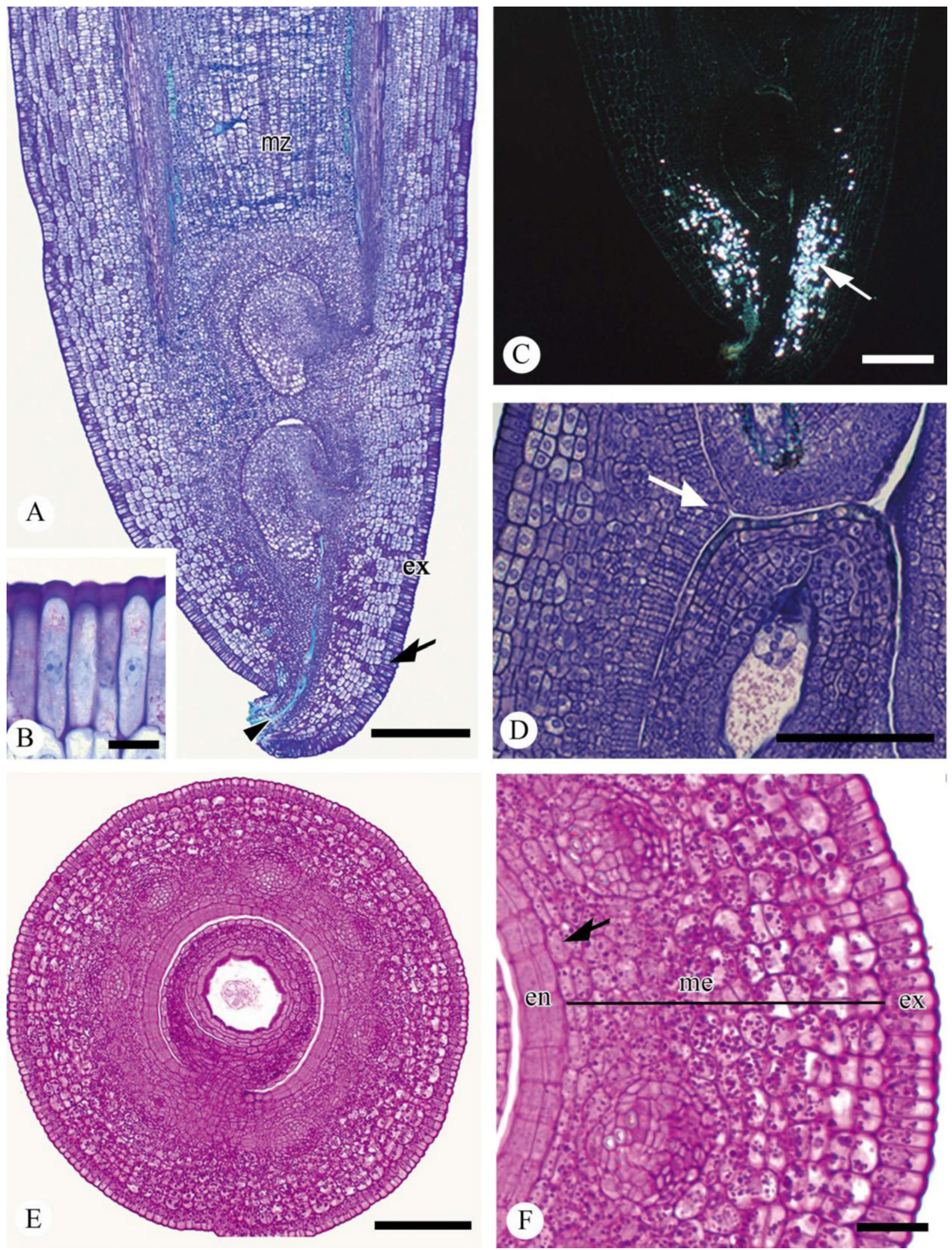

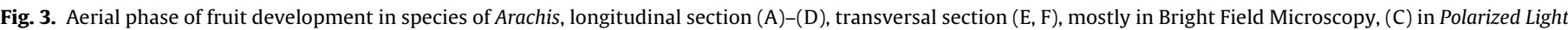

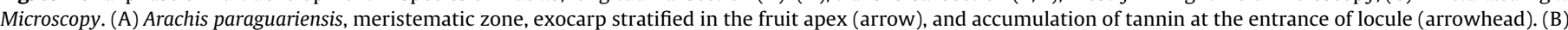

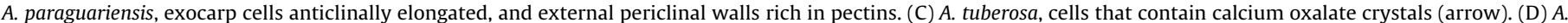

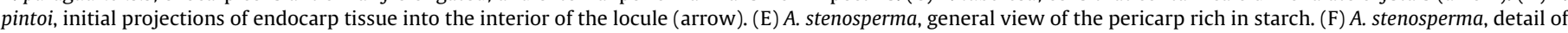

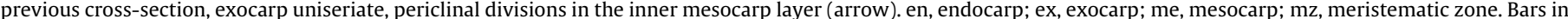
(A), (C) and (E) $=200 \mu \mathrm{m}$, (B) and (F) $=20 \mu \mathrm{m},(D)=100 \mu \mathrm{m}$. 
portion of the ovary, where the style was attached, the zone of abscission can be seen, with accumulated phenolic substances, which were identified as tannins using vanillin (Fig. 3A). In addition, in all of the species the apical cells of this region have lignified walls.

The mesocarp is composed of starch-rich cells (Fig. 3E and F). In the outer mesocarp, adjacent to the exocarp, there are cells with periclinal and anticlinal divisions, forming cell layers that are derived from the subdermal layer of the mesophyll of the ovary; while internally, near the endocarp, the divisions are predominantly periclinal (Fig. 3F). The vascular bundles have differentiated tracheary elements and have lateral anastomoses. There are numerous cells that contain calcium oxalate crystals near the apical region of the ovary and young fruit that persist in other stages of development in A. tuberosa (Fig. 3C).

The endocarp is formed from the inner epidermis of the ovary, and comprised of four layers of elongated periclinal cells (Fig. 3F). In the dorsal region, between the developing seeds, periclinal divisions are more pronounced, forming the initial projections of endocarpic tissue in the interior of the seed chamber (Fig. 3D).

Stage III: This stage includes the immature development of the fruit underground, and is characterized by conspicuous growth caused by the expansion and division of cells. In all species, it appears that the maturation process of the fruit leads to the formation of the fruit articulations with the uneven development of the segments, in that the proximal segment develops before the distal segment (Fig. 1E). The majority of the observations detailed below refer to the pericarp of the proximal seminiferous portion of the fruit.

The fruits of $A$. stenosperma (Fig. 1E), A. paraguariensis and A. pintoi now lose their pigmentation and become whitish yellow.

As the fruit develops underground, the exocarp cells are broken, which is the result of the fruit rubbing against soil particles (Fig. 4B). The persistent exocarp cells differentiate into trichomes (Fig. 4C). Later in development, below the exocarp, the cells of the third mesocarp layer start to divide periclinally which is the beginning of the formation of a periderm (Fig. 4C). Next to the vascular bundles, in the region adjacent to the xylem, there are idioblasts that contain tannins (Fig. $4 \mathrm{~A}$ and $\mathrm{B}$ ).

The cells of the inner portion of the endocarp have intense mitotic activity. Initially the divisions are predominantly periclinal and later they are in various directions (Fig. 4A and B). This results in forming a "seed cushion", parenchyma with large vacuolated cells with starch. This tissue fills the entire seed chamber (Fig. 4B). In the external portion of the endocarp, adjacent to the mesocarp, there are three to five layers of cells that elongate in different directions (Fig. 4A-E). The pronounced proliferation of the endocarp is the main factor responsible for the significant increase in diameter of the fruit. The growth is more pronounced on the dorsal side of the proximal segment (Fig. $4 \mathrm{H}$ ). As a result of the uneven growth, the fruits are positioned horizontally in the soil with the ventral part of the fruit on top.

In the region between the two segments of the developing fruit, proliferation of the endocarp begins which is very intense and produces projections towards the interior of the seed chamber (Fig. 4F). The cells that make up the core material of this region are embedded in a substance of pectic nature (Fig. $4 \mathrm{~F}$ and $\mathrm{G}$ ). As the proximal segment matures, the projections of the endocarp become fully coalesced. Later, due to the development of a meristem, a tissue forms that separates the distal and proximal segments. It constitutes the isthmus (Fig. $4 \mathrm{H}$ ) that separates the segments of fruit (Fig. 1E). It is only after the meristematic activity has stopped that the distal segment begins to increase in diameter and the pericarp layers differentiate as in the proximal segment. The vascular bundles that supply the proximal segment of the fruit converge in the region of the isthmus, and some of them fuse (Fig. 4I). In transverse section, the isthmus resembles the primary stem of a dicotyledon, with the usual tissue system epidermis, cortex, vascular cylinder, and medulla (Fig. 4I).

Stage IV: Designated as the mature underground fruit. The mature fruit is dry, indehiscent and has two segments. At this stage the protective layers of the fruit are formed by the periderm and exocarp (with trichomes); both coexist in the later stages of the fruit development. The exocarp presents capitate unicellular trichomes in A. stenosperma (Fig. 5A and B) versus non-capitate in the other species (Fig. 5C). The cells in the outer layer of the periderm and exocarp have walls that contain suberin and lignin. In all species it is common for the more external portions of the periderm to flake, which is more pronounced in the regions of the vascular bundles. The periderm isolates the exocarp and one or two outer layers of mesocarp. In A. pintoi, the cells of the two most external mesocarp layers contain tannins (Fig. $5 \mathrm{E}$ and I).

The sclerenchyma tissue originating from the outer region of the endocarp comprises three to five layers of cells that are predominantly different types of sclereids and fibers (Fig. 5F). They are arranged in groups that are oriented in different directions but do not form definite strata. Moreover, in all species, except $A$. tuberosa, the most external layer of sclerenchyma is made of sclereids that are basically isodiametric and contain calcium oxalate crystals (Fig. 5G). Unlike other species, the fruits of A. paraguariensis have projections in the sclerenchyma stratum that enter the mesophyll in the interfascicular region (Fig. 5H).

The mature mesocarp has 12-15 bundles, interconnected by anastomoses, responsible for the reticulated appearance of the mature pericarp in species of Arachis. The mesocarp of all of the studied species has three to five layers of obliterated cells, associated to groups of large parenchymatic cells (Fig. $5 \mathrm{H}$ and I). In the majority of the species, the bundles have sclerenchyma cap (Fig. 5I and $\mathrm{K}$ ). However, in $A$. paraguariensis these caps are not present (Fig. $5 \mathrm{H}$ and J). The cells of the endocarp are completely collapsed (Fig. $5 \mathrm{H}$ and I), giving rise to the whitish papyraceous tissue present in mature fruits (Fig. 5).

There is no evidence of dehiscence lines in the middle region of each seed chamber. However, in the apical regions of each one, the sclerenchyma tissue is projected towards the ventral and dorsal bundles, forming keels in the fruits of all species (Fig. 6A). The isthmus of mature fruits, in all of the species, has secondary growth with a well-developed periderm, lenticels and bundles with vascular cambium (Fig. 6B).

In A. tuberosa the medulla cells collapse forming a cavity in the interior of the isthmus (Fig. 6D), similar to fistulous stems, whereas in the other species the medulla region differentiates into tracheoid cells (Fig. 6B, C, E, F), which are elongate with pitted to reticulated thickness on the lateral and terminal walls (Fig. 6C and F). In $A$. stenosperma and $A$. pintoi the medulla region is completely differentiated with tracheoid cells (Fig. 6B), while in A. paraguariensis these are only present in the central region of the medulla. Similarly to what happens to the pericarp of $A$. paraguariensis, the vascular bundles of the mature isthmus do not have a sclerenchyma cap (Fig. 6E).

The fruit development characters of all species analyzed are compiled in Table 1, in order to summarize and compare the data presented in this study.

\section{Discussion}

As in Arachis hypogaea (Jacobs, 1947; Pattee and Mohapatra, 1987; Periasamy and Sampoornam, 1984; Pettit, 1895; Smith, 1950; Zamski and Ziv, 1976; Ziv, 1981), also the wild species studied develop a meristem below the ovary, which directs the fruit into the soil. Although the terminology used for the peduncle that buries the fruit is controversial, the term gynophore is commonly 


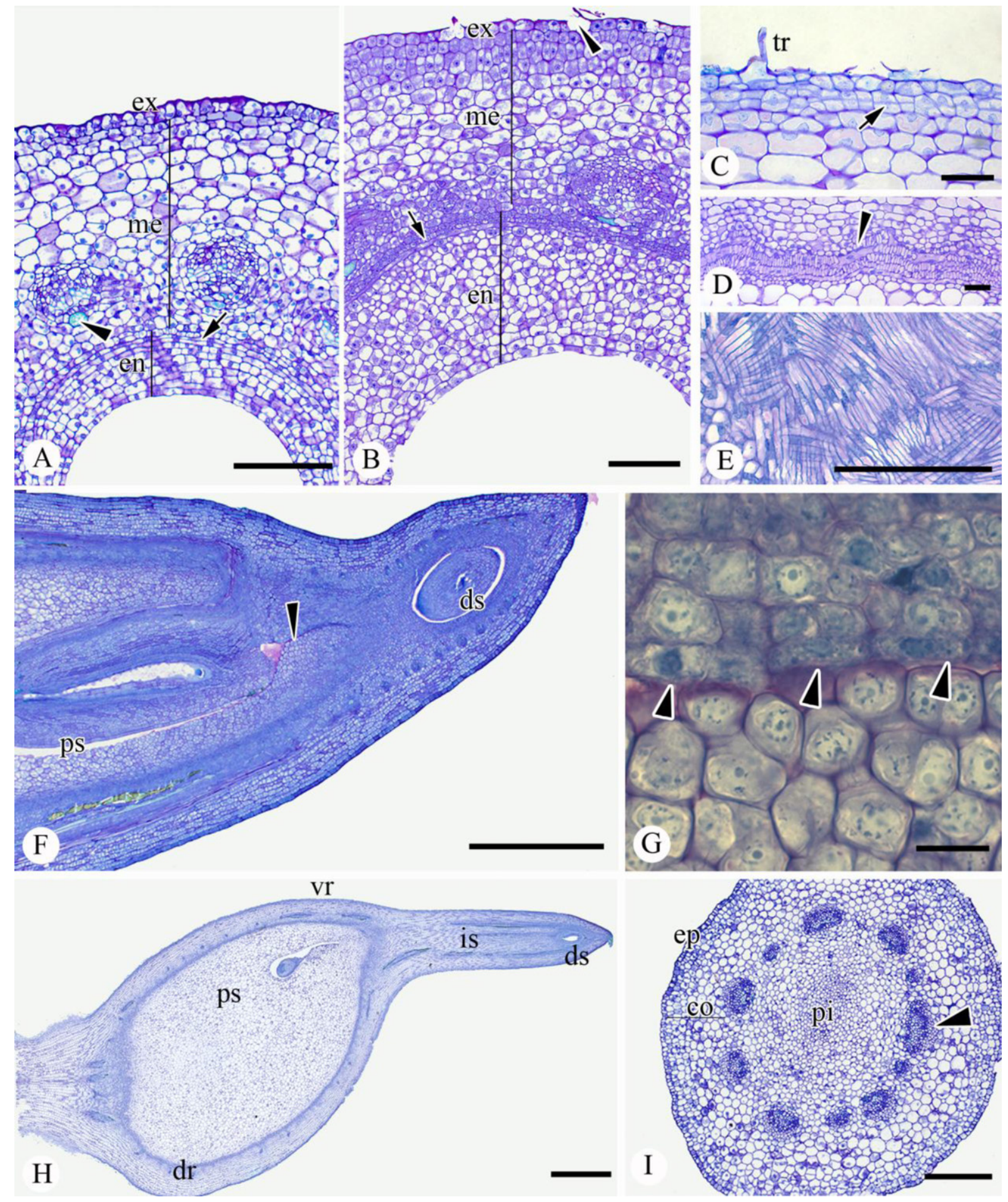

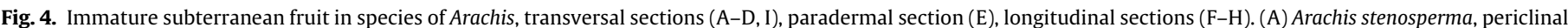

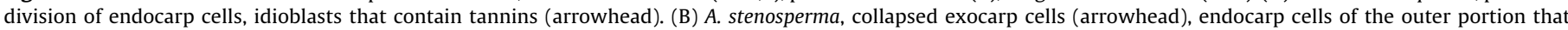

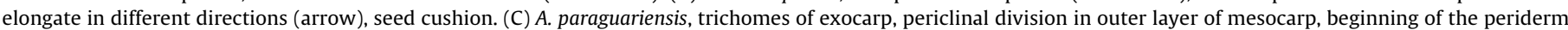

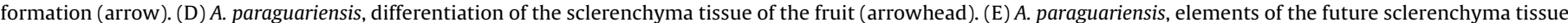

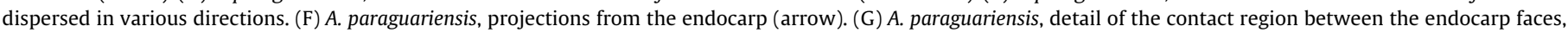

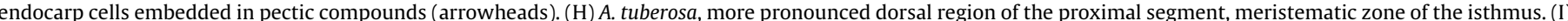

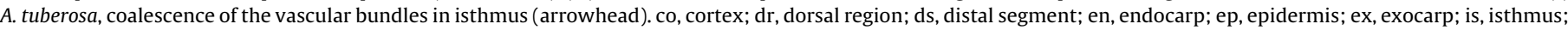
me, mesocarp; pi, pith; ps, proximal segment; vr, ventral region. Bars in $(A)-(D)=100 \mu \mathrm{m},(\mathrm{E})$ and $(\mathrm{G})=500 \mu \mathrm{m},(\mathrm{F})=20 \mu \mathrm{m},(\mathrm{H})=200 \mu \mathrm{m}$.

used in the literature (Moctezuma, 2003), especially for A. hypogaea, where an isthmus between seeds is rarely noticed. In wild species, the presence of the isthmus raises questions about eventual ontogenetic and anatomical similarities of both, the one that connects the seeded fruit segments (isthmus), and the one that connects the proximal fruit segment to the plant. During their growth into the soil and the subterranean development, the fruits of the studied species exhibit various peculiar characteristics. 


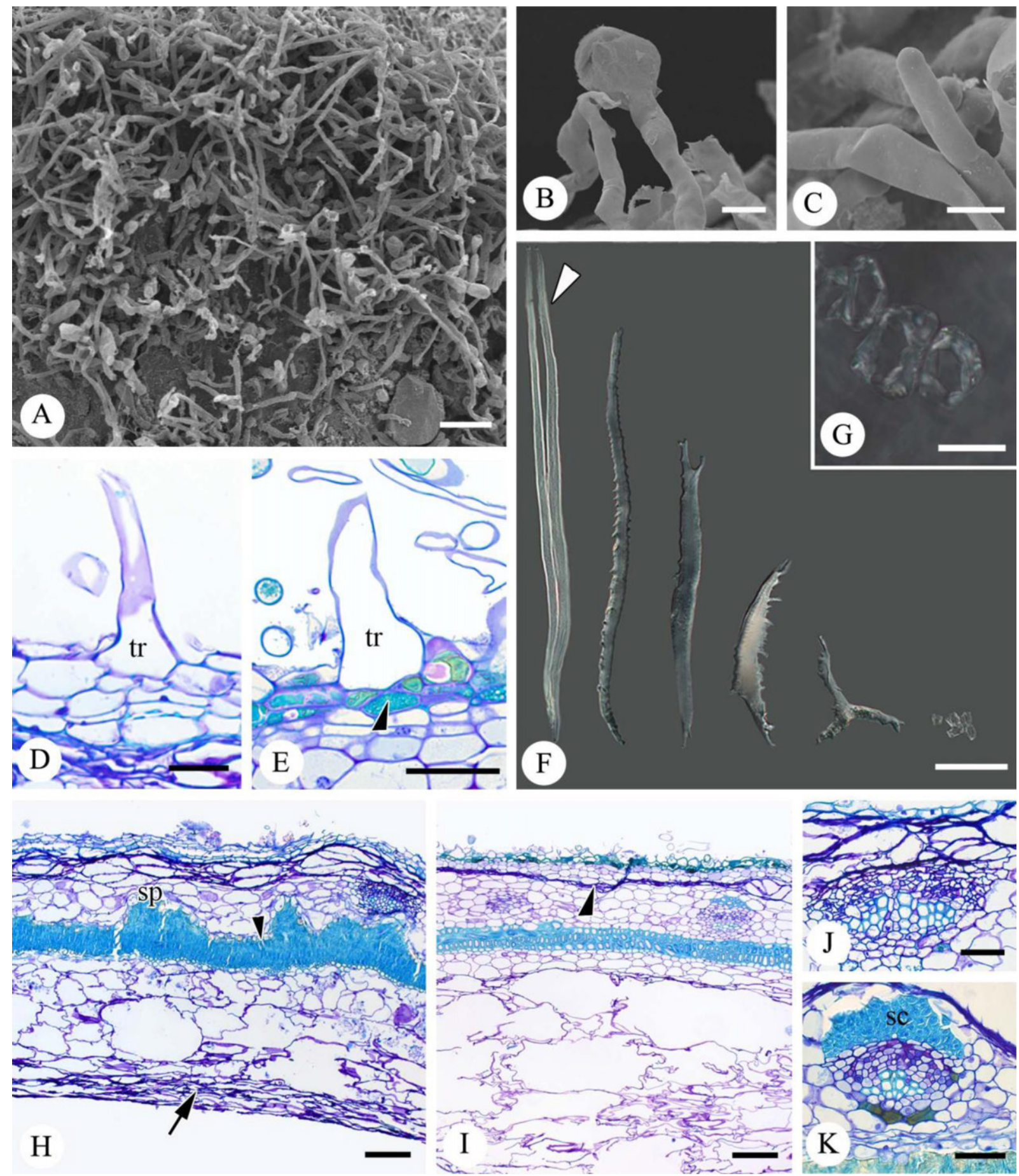

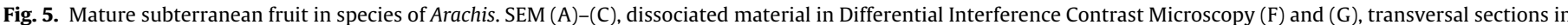

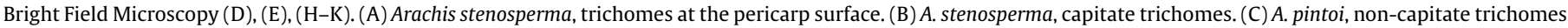

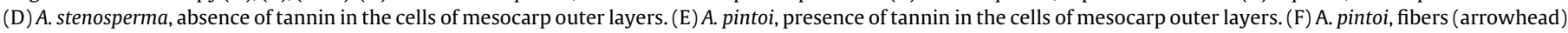

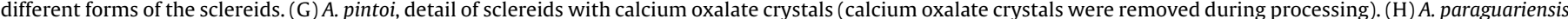

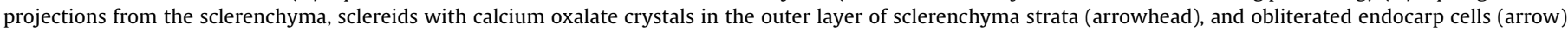

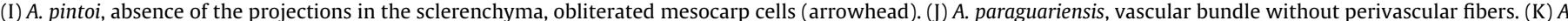

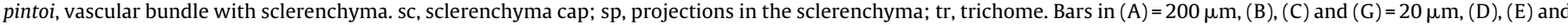
$(\mathrm{J})=50 \mu \mathrm{m},(\mathrm{F}),(\mathrm{H}),(\mathrm{I})$ and $(\mathrm{K})=100 \mu \mathrm{m}$.

The presence of lignified cells in the apex of the immature fruits in their aerial phase helps the fruits penetrate the soil, which was reported also for A. hypogaea by Shushu and Cutter (1990). In addition, the presence of pectic compounds in the outer periclinal exocarp cell walls is probably related to aid in the movement of the fruits through the soil.
The majority of the cellular expansion and division occurs after the young fruit penetrates the soil. According to Zamski and Ziv (1976), in A. hypogaea, the factors that stimulate the subterranean development of the fruits are mechanical stimulation, caused by the friction with soil particles, and absence of light. For this reason, growth in diameter of the fruits has not been observed during the 

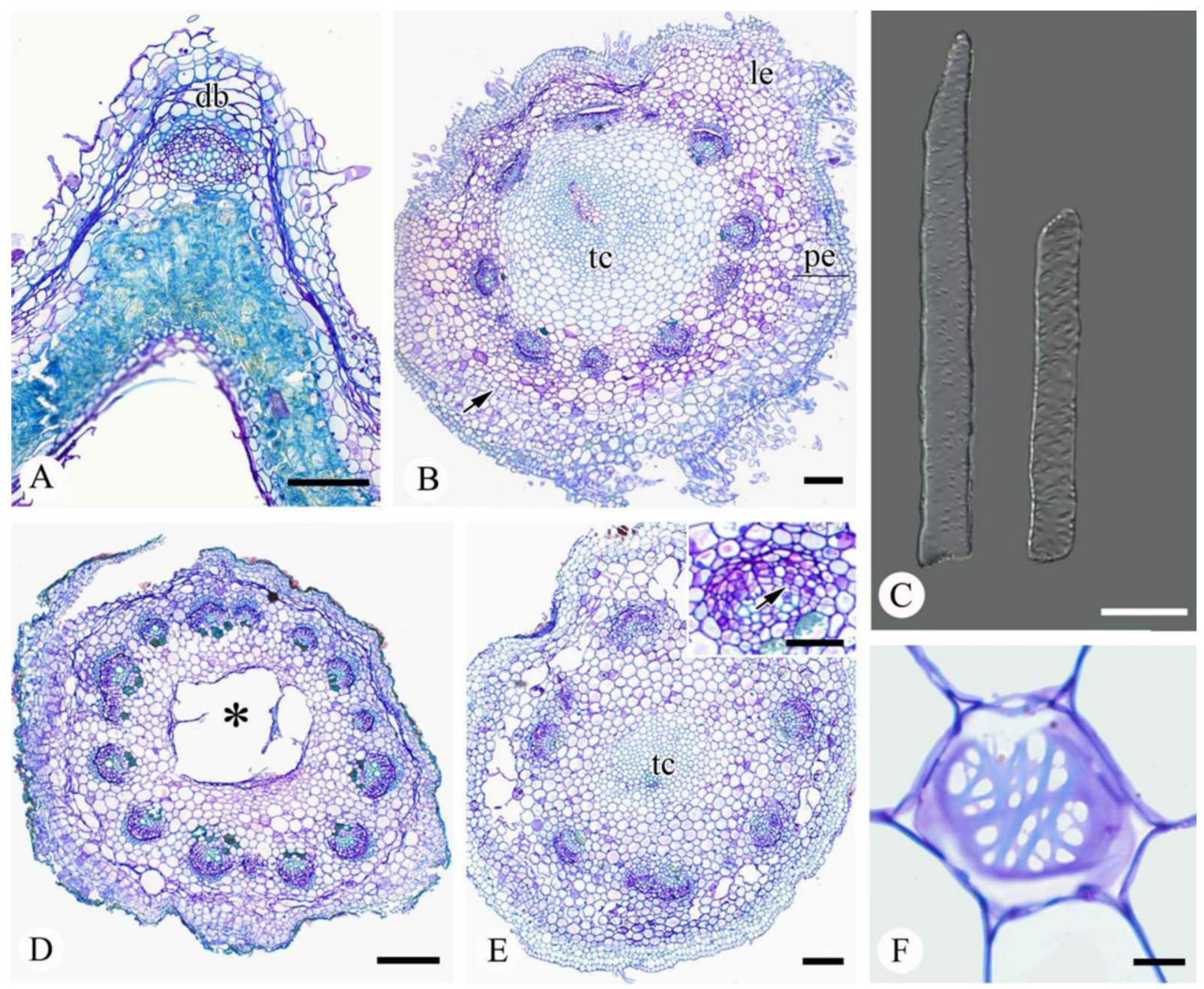

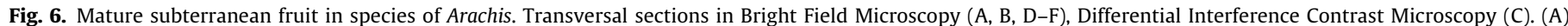

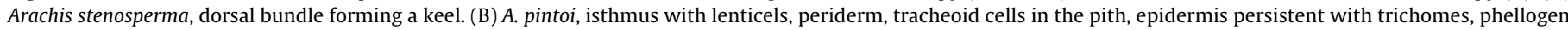

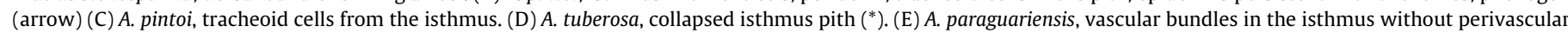

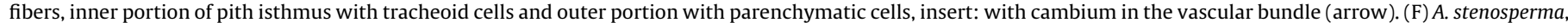

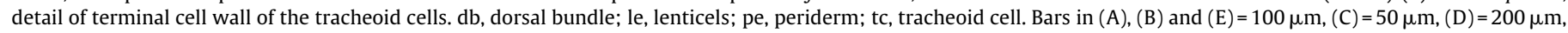
$(\mathrm{F})=20 \mu \mathrm{m}$.

aerial phase of development in the cultivated species and in the wild species that were analyzed.

Even before the fruit enters the soil, the endocarp has periclinal cellular divisions that are more conspicuous between the young seeds in the dorsal portion of the fruit. When the fruit becomes subterranean, these divisions increase, creating the projections of the endocarp. In the regions where the projections are in contact with each other, the cells have walls rich in pectic compounds similar to those reported by Paiva and Oliveira (2004) for Hymenaea stigonocarpa Mart. ex Hayne, which is a characteristic related to the coalescence of the projections. With the complete coalescence of the projections, a meristematic region is established that separates and distances the segments of the fruit. The development of the isthmus can be considered as a strategy to disperse the seeds as far as possible from the parent plant, because geocarpy limits the dispersion and distribution of species of this genus (Simpson et al., 2001).

According to Conagin (1959), the isthmus of the wild species of Arachis is structurally similar to the gynophore, in relation to its epidermis, cortex, vascular cylinder and medulla, and was referred

Table 1

Diagnostic development characters observed on fruit of four wild species of Arachis.

\begin{tabular}{|c|c|c|c|c|c|c|}
\hline Species & $\begin{array}{l}\text { Pericarp trichome } \\
\text { type }\end{array}$ & $\begin{array}{l}\text { Sclerenchyma cap } \\
\text { in the bundles }\end{array}$ & Tracheoid cells & $\begin{array}{l}\text { Localization of } \\
\text { crystalliferous cells }\end{array}$ & $\begin{array}{l}\text { Cells of mesocarp outer } \\
\text { layers with tannin }\end{array}$ & $\begin{array}{l}\text { Projections in the } \\
\text { sclerenchyma tissue }\end{array}$ \\
\hline A. paraguariensis & Non-capitate & Absent & $\begin{array}{l}\text { Present, central } \\
\text { region of medulla }\end{array}$ & $\begin{array}{l}\text { Sclerenchyma } \\
\text { tissue }\end{array}$ & Absent & Present \\
\hline A. pintoi & Non-capitate & Present & $\begin{array}{l}\text { Present, medulla } \\
\text { completely }\end{array}$ & $\begin{array}{l}\text { Sclerenchyma } \\
\text { tissue }\end{array}$ & Present & Absent \\
\hline A. stenosperma & Capitate & Present & $\begin{array}{l}\text { Present, medulla } \\
\text { completely }\end{array}$ & $\begin{array}{l}\text { Sclerenchyma } \\
\text { tissue }\end{array}$ & Absent & Absent \\
\hline A. tuberosa & Non-capitate & Present & Absent & $\begin{array}{l}\text { Apical region of the } \\
\text { fruit }\end{array}$ & Absent & Absent \\
\hline
\end{tabular}


to as a secondary gynophore by Zharare et al. (1998). In present study it was verified that the isthmus corresponds to a false septum. Presence of a false septum has been reported for the fruits of other representatives of the family (Nakamura and Oliveira, 2005; Oliveira et al., 2007; Roth, 1977), and is considered an important characteristic that helps to define a group of genera in the tribe Dalbergiae (Polhill, 1981).

In the mature isthmus of $A$. stenosperma, $A$. pintoi and $A$. paraguariensis, the medullary region differentiates into tracheoid cells or tracheoid idioblasts that are elongated cells with pitted to reticulated wall thickness (Foster, 1956). The presence of this type of cell is probably related to the short-distance water transport and maintenance of the water status in the developing fruit, as observed in storage tracheids found in fruits of Raphanus sativus L. by Kaniewski (1967).

The presence of cells containing calcium oxalate crystals is common in all species studied and is a characteristic of the pericarp of numerous families. These mineral deposits in fruits could be involved in controlling excess calcium, keeping the ion as internal reserve (Webb, 1999). All of the species of Arachis have crystals in their pericarps. In almost all species, these crystals are located in the sclereids in the outer portion of the sclerenchyma tissue. In species of Solanum L., Chiarini and Barboza (2007) also verified the presence of crystals in the interior of fibers that are probably related to the mechanism that controls excess calcium in the plant. Exceptionally, in A. tuberosa, the crystaliferous cells are in the apex of the developing fruit. In this species the initial development of the fruit occurs in the soil and probably the crystals act as protection against herbivores, as it was observed in Medicago sativa L. (Korth et al., 2006).

The sclerenchyma of the analyzed wild species originates in the outer portion of the endocarp, adjacent to the mesocarp, similar to that reported for A. hypogaea by Winton (1904), Russell (1931) and Halliburton et al. (1975). According to Winton (1904), the sclerenchymatous extract of the fruits of $A$. hypogaea comprises tangentially oriented fibers. However, Halliburton et al. (1975) reinterpreted this layer as being made of only sclereids. In the present work, there was a predominance of sclereids of different forms that had sinuous walls. In addition, the sclerenchymatic tissue is also made of fibers oriented in various directions, without forming definite strata. In A. paraguariensis, the sclerenchyma layer has projections similar to those observed in A. hypogaea (Halliburton et al., 1975). However, the projections not only follow the vascular bundles but are also present in the interfascicular region.

Idioblasts containing tannins associated to the vascular bundles in the wild species of Arachis were found in A. pintoi in the most external layer of the periderm. Such tannin-containing idioblasts are thought to be a strategy to protect the seed and embryo against herbivores and microorganisms (Carvalho et al., 1999). Its adstringent properties inhibit digestion and cause damage to the plasma membrane of many microorganisms (Appel, 1993).

Various studies mention the presence of trichomes on the fruits of A. hypogaea (Pettit, 1895; Reed, 1924; Russell, 1931; Winton, 1904) that are similar to those observed in the present study; however, they did not elucidate on the origin of these trichomes. In the wild species of Arachis the trichomes originate from portions of the exocarp which are not destroyed by friction with the soil particles.

With the exception of $A$. stenosperma, which has capitate trichomes, the trichomes of the species studied here are non-capitate and similar to root hairs, as they were observed similarly by Pettit (1985) and Reed (1924) in A. hypogaea. The functions of these trichomes are probably related to the absorption of nutrients, as suggested by Wissuwa and Ae $(1999,2001)$, and to attach the mature fruits to the soil particles (Waldron, 1919).
The fruit of Arachis lacks an active mechanism of dehiscence, but the pericarp fractures along the dorsal and ventral regions when subjected to mechanical pressure characterize it as potentially dehiscent (Smith, 1950). Although a line of dehiscence was not observed on the pericarps of the investigated species of Arachis, particularly in the apical region of the segments, it is possible to see regions where the sclerenchyma tissue is projected towards the dorsal and ventral bundles resulting in a keel-like structure. This area could be a zone of weakness in the pericarp, through which the seeds germinate. Tisserant (1950) called this pattern in A. hypogaea "late dehiscence".

Fahn and Zohary (1955) affirm that presence of a fragile tissue region in a fruit is not enough to consider it to be dehiscent, and that other factors must be present, such as the crossed orientation of the strata of sclerenchyma cells and the micelles that compose the walls of these cells. Considering that dehiscence is defined as the natural exposure or release of the seeds through an opening in the pericarp (Spjut, 1994), and that there are fibers and sclereids oriented in various directions that do not form different strata, normal conditions probably do not generate the forces needed for the fruit of Arachis to be actively dehiscent. Therefore, the fruits of the Arachis studied should be considered indehiscent.

All of the species studied have fruits with two segments, typical of the wild species of the genus, with the exception of A. triseminata that has fruits with three segments (Krapovickas and Gregory, 1994). This characteristic was first described in A. monticola by Burkart (1939). In the commercially used species A. hypogaea segmented fruits are uncommon (Smith, 1950), since that feature was suppressed during peanut domestication because it hinders the fruit harvest (Zharare et al., 1998). During the ripening process, the proximal segment develops before the distal segment, which was observed by Conagin (1959) in A. monticola and A. villosa, both in section Arachis. In A. hypogaea, which lacks an isthmus, the seeds grow like in the wild species, but in an attenuated way, giving the impression that the fruit segments develop simultaneously (Krapovickas and Gregory, 1994).

In general, the pattern of development of the fruits of wild species of Arachis can be compared to what is known about $A$. hypogaea from Waldron (1919) and two other wild species of section Arachis that were studied by Conagin (1959). Although the geocarpic fruits of the wild species studied are similar, this study identified potentially diagnostic infrageneric characters. Notable characters are the types of trichomes on the pericarp, the presence of a sclerenchyma cap in the bundles of the pericarp in the seminiferous regions and isthmus, the presence of tracheoid cells in the pith of the isthmus, the location of crystalliferous cells, the presence of tannins in the cells of the mesocarp' outer layers and the presence of projections in the sclerenchyma tissue.

\section{Acknowledgments}

Thanks to the Laboratório de Anatomia Vegetal da Universidade Federal do Rio Grande do Sul (LAVEg), the Coordenação de Amparo ao Aperfeiçoamento de Pessoal de Nível Superior (CAPES) for the doctoral grant awarded to the first author, and the Conselho Nacional de Desenvolvimento Científico e Tecnológico (CNPq) for the research grants awarded to the other authors.

\section{References}

Appel, H.M., 1993. Phenolics in ecological interactions: the importance of oxidation. J. Chem. Ecol. 19, 1521-1551.

Barroso, G.M., Morim, M.P., Peixoto, A.L., Ichaso, C.L.F., 1999. Frutos e sementes: morfologia aplicada à sistemática de dicotiledôneas. Editora da Universidade Federal de Viçosa, Viçosa. 
Bobrov, A.V.F.C.H., Endress, P.K., Melikian, A.P., Romanov, M.S., Sorokin, A.N., Bejer ano, A.P., 2005. Fruit structure of Amborella trichopoda (Amborellaceae). Bot. J. Linn. Soc. $148,265-274$.

Burkart, A., 1939. Estudios sistemáticos sobre las Leguminosas-Hedisareas de la República Argentina y regiones adyacentes. Darwiniana 3, 117-302.

Carvalho, J.C.T., Gosmann, G., Schenkel, E.P., 1999. Compostos fenólicos simples e heterosídicos. In: Simões, C.M.O., Schenkel, E.P., Gosman, G., Mello, J.C.P., Mentz, L.A., Petrovick, P.R. (Eds.), Farmacognosia: da planta ao medicamento. Universidade UFRGS, UFSC, Porto Alegre, Florianópolis, pp. 433-449.

Chamberlain, C.J., 1932. Methods in Plant Histology. University of Chicago Press, Chicago.

Chiarini, F., Barboza, G., 2007. Anatomical study of different fruit types in Argentine species of Solanum subgen Leptostemonum (Solanaceae). Anales Jard. Bot. Madrid 64, 165-175.

Conagin, C.H.T.M., 1959. Desenvolvimento dos frutos nas espécies selvagens de amendoim (Arachis spp.). Bragantia 18, 51-70.

Doyle, J.A., 2000. Phylogeny of vascular plants. Annu. Rev. Ecol. Syst. 29, 567-599.

Fahn, A., Zohary, M., 1955. On the pericarpial structure of the legumen, its evolution and relation to dehiscence. Phytomorphology 5, 99-111.

Foster, A.S., 1956. Plant idioblasts: remarkable examples of cell specialization. Protoplasma 46, 184-193.

Gabriel, B.L., 1982. Biological Electron Microscopy. Van Nostrand Reinhold, New York.

Gerrits, P.O., Smid, L., 1983. A new less toxic polymerization system for the embedding of soft tissues glycol methacrylate and subsequent preparing of serial sections. Am. J. Microsc. 132, 81-85.

Gerstberger, P., Leins, P., 1978. Rasterelektronmikroskopische Untersuchungen an Blütenknospen von Physalis philadelphica (Solanaceae). Anwendung einer neuen Präparationsmethode. Ber. Dtsch. Bot. Ges. 91, 381-387.

Guerin, H.P., Delaveau, P.G., Paris, R.R., 1971. Localisations histochimiques II:Procédés de pigments flavoniques. Application à quelques Phanérogames. Bull. Soc. Bot. France 118, 29-36.

Halliburton, B.W., Wolfgang, G., Byrne, J.N., 1975. An anatomical study of the pericarp of Arachis hypogaea with special emphasis on the sclereid component. Bot. Gaz. $136,219-223$.

Haro, R.J., Mantese, A., Otegui, M.E., 2011. Peg viability and pod set in peanut: Response to impaired pegging and water deficit. Flora 206, 865-871.

Jacobs, W.P., 1947. The development of the gynophore of the peanut plant (Arachis hypogaea L.) I. The distribution of mitosis, the region of greatest elongation, and the maintenance of vascular continuity in the intercalary meristem. Am. J. Bot. $34,361-371$.

Jensen, W.A., 1962. Botanical Histochemistry: Principles and Practice. W. H. Freeman, San Francisco.

Johansen, D.A., 1940. Plant Microtechnique. McGraw-Hill, New York.

Kaniewski, K., 1967. Development of the hydrocyte (storage tracheid) system in the pericarp of Raphanus sativus L. Bull. Acad. Pol. Sci. Biol. 15, 171-180.

Korth, K.L., et al., 2006. Medicago truncatula mutants demonstrate the role of plant calcium oxalate crystals as an effective defense against chewing insects. Plant Physiol. 141, 188-195.

Krapovickas, A., Gregory, W.C., 1994. Taxonomía del género Arachis (Leguminosae). Bonplandia 8, 1-186.

Lavin, M., Pennington, R.T., Klitgaard, B.B., Sprent, J.I., Lima, H.C., Gasson, P.E., 2001 The dalbergioid legumes (Fabaceae): delimitation of a pantropical monophyletic clade. Am. J. Bot. 88, 503-533.

Le Roux, M.M., Wyk, B.E.V., Boatwright, J.S., Tilney, P.M., 2011. The systematic significance of morphological and anatomical variation in fruits of Crotalaria and related genera of tribe Crotalarieae (Fabaceae). Bot. J. Linn. Soc. 165, 84-106.

Leite, V.G., Maquiafável, F.S., Moraes, D.P., Teixeira, S.P., 2009. Fruit anatomy of Neotropical species of Indigofera (Leguminosae Papilionoideae) with functional and taxonomic implications. J. Torrey Bot. Soc. 136, 203-211.

McDowell, E.M., Trump, B.R., 1976. Histological fixatives for diagnostic light and electron microscopy. Arch. Pathol. Lab. Med. 100, 405-414.

Moctezuma, E., 2003. The peanut gynophore: a developmental and physiological perspective. Can. J. Bot. 81, 183-190.

Nakamura, A.T., Oliveira, D.M.T., 2005. Morfoanatomia e ontogênese da sâmara de Pterocarpus violaceus Vogel (Fabaceae: Faboideae). Rev. Bras. Bot. 28, 375-387.
Narang, A.K., Govil, C.M., 1978. Developmental anatomy of pericarp in some Papilionaceae. J. Indian Bot. Soc. 57, 205-210.

Nemoto, T., Ohashi, H., 2003. Diversity and evolution of anatomical structure of loments in tribe Desmodieae (Papilionoideae). In: Klitgaard, B.B., Brineau, A. (Eds.), Advances in Legume Systematics. Royal Botanic Gardens, Kew, pp. 395-412.

O'Brien, T.O., McCully, M.E., 1981. The Study of Plant Structure Principles and Selected Methods. Thermarcarphi Pty, Melbourne.

Oliveira, D.M.T., Siqueira, C.A.N., Nakamura, A.T., 2007. Anatomia e ontogênese da sâmara de Centrolobium tomentosum Guill. ex Benth (Leguminosae; Papilionoideae). Rodriguesia 58, 231-247.

Paiva, E.A.S., Oliveira, D.M.T., 2004. Ontogenesis of fruit pulp layer of Hymenaea stigonocarpa (Fabaceae: Caesalpinioideae). Aust. J. Bot. 52, 677-683.

Pate, J.S., Kuo, J., 1981. Anatomical studies of legume pods - a possible tool in taxonomic research. In: Polhill, R.M., Raven, P.H. (Eds.), Advances in Legume Systematics. Royal Botanic Gardens, Kew, pp. 903-912.

Pattee, H.E., Mohapatra, S.C., 1987. Anatomical changes during ontogeny of the peanut (Arachis hypogaea L.) fruit: mature megagametophyte through heartshaped embryo. Bot. Gaz. 148, 156-164.

Periasamy, K., Sampoornam, C., 1984. The morphology and anatomy of ovule and fruit development in Arachis hypogaea. Ann. Bot. 53, 399-411.

Pettit, A.S., 1895. Arachis hypogaea L. Mem. Bot. Torrey Club 4, 275-296.

Polhill, R.M., 1981. Dalbergieae. In: Polhill, R.M., Raven, P.H. (Eds.), Advances in Legume Systematics. Royal Botanical Gardens, Kew, pp. 233-242.

Reed, E.L., 1924. Anatomy, embryology, and ecology of Arachis hypogaea. Bot. Gaz. 78, 289-310.

Roth, I., 1977. Fruits of angiosperms. In: Linsbauer, K. (Ed.), Handbuch der Pflanzenanatomie. Gebr. Borntraeger, Berlin, pp. 1-675

Russell, M.W., 1931. Étude organogénique du fruit de l'arachide. Rev. Bot. Appl. Agric. Trop. $11,885-890$.

Sass, J., 1951. Botanical Microtechnique. The Iowa State College Press, Ames, Iowa.

Shushu, D.D., Cutter, E.G., 1990. Growth of the gynophore of the peanut Arachis hypogaea 1. Intact and decapitated gynophores. Can. J. Bot. 68, 955-964.

Simpson, C.E., Krapovickas, A., Valls, J.F.M., 2001. History of Arachis including evidence of A. hypogaea L. progenitors. Peanut Sci. 28, 78-80.

Smith, B.W., 1950. Arachis hypogaea: aerial flowers and subterranean fruit. Am. J. Bot. 37, 802-815.

Spjut, R.W., 1994. A systematic treatment of fruit types. Mem. N. Y. Bot. Gard. 70, $1-182$.

Sytsma, K.J., Pirez, J.C., 2001. Plant systematics in the next 50 years - re-mapping the new frontier. Taxon 50, 713-732.

Tisserant, R.P.C., 1950. L'arachide a-t-elle-un fruit indehiscent? Bull. Soc. Bot. France 97, 175-177, 185-187.

Valls, J.F.M., Simpson, C.E., 2005. Species of Arachis L. (Leguminosae) from Brazil, Paraguay and Bolivia. Bonplandia 14, 35-64.

Waldron, R.A., 1919. The peanut (Arachis hypogaea), its history, histology, physiology, and utility. Contr. Bot. Lab. Univ. Pensylvania 4, 302-340.

Webb, M.A., 1999. Cell-mediated crystallization of calcium oxalate in plants. Plant Cell 11, 751-761.

Winton, A.L., 1904. The anatomy of the peanut with special reference to its microscopic identification in food products. Connecticut Agr. Exp. Sta. Annual Report 1904, 191-198.

Wissuwa, M., Ae, N., 1999. Genotypic variation for phosphorus uptake from hardly soluble iron- phosphate in groundnut (Arachis hypogaea L.). Plant Soil 206, 163-171.

Wissuwa, M., Ae, N., 2001. Genotypic differences in the presence of hairs on roots and gynophores of peanuts (Arachis hypogaea L.) and their significance for phosphorus uptake. J. Exp. Bot. 52, 1703-1710.

Zamski, E., Ziv, M., 1976. Pod formation and its geotropic orientation in the peanut Arachis hypogaea L., in relation to light and mechanical stimulus. Ann. Bot. 40, 632-636.

Zharare, G.E., Blamey, F.P.C., Asher, C.J., 1998. Initiation and morphogenesis of groundnut (Arachis hypogaea L.) pods in solution culture. Ann. Bot. 81, 391-396.

Ziv, M., 1981. Photomorphogenesis of the gynophore, pod, and embryo of peanut, Arachis hypogaea L. Ann. Bot. 48, 353-359. 